\title{
INTERNATIONAL RED CROSS MEETINGS IN ISTANBUL
}

These important meetings which were announced in earlier issues of International Revierw took place from 29 August to 13 September 1969.

They began with the XXX session of the League Board of Governors, that institution's supreme policy-making body. A ceremony to ccmmemorate the fiftieth anniversary of the League's foundation was held on 5 September.

The XXI International Conference of the Red Cross was attended from 6-13 September by more than 700 delegates representing 92 governments, the ICRC, the League and 84 National Red Cross, Red Crescent and Red Lion and Sun Societies. Apart from two plenary sessions it included the meetings of the International Humanitarian Law Commission and the General Commission. The main subject of the proceedings was the development of humanitarian law.

The Conference adopted 24 resolutions. The full text of these will be given in our next issue, at the same time as an article on the work and significance of the international meetings which have just been held in Istanbul. 